\title{
NPA and Its Impact on Asset Quality- Bankers' Perception
}

\author{
Salini R Chandran, K. Alamelu
}

\begin{abstract}
NPA is a burning issue in the Indian Banking Sector. So the main purpose of the paper is to identify the trends in the NPA and to examine bankers' perception on reasons for NPA and to suggest measures for minimizing NPA. The study is based on both primary data and secondary data. Secondary data is collected for a period of 16 years from 2002 to 2017. Percentages, growth rates, mean, standard deviation, Z-test and chi-square tests are the major tools of analysis. The study has found that over the years there is tremendous growth in the NPA of banks. The major reason for this was wilful default from the part of borrowers and siphoning of funds for other purposes. The significant contribution of the study will be pragmatic suggestions on improving asset quality of banks in India. It will throw new insights on effective credit management by banks.
\end{abstract}

Keywords: Credit Growth, Doubtful, NPA, Substandard, Wilful Defaulters,

\section{INTRODUCTION}

Non-Performing Assets (NPA) is defined as a credit facility in respect of which the interest and/or instalment is due for a period of 90 days. In simple NPA means any asset which ceases to generate any income to the banks. Based on the period, NPA may be classified as substandard assets, doubtful assets and loss assets. The volume of NPA of a bank is an indicator of banks' efficiency in credit risk management and resource allocation. The Reserve Bank of India, in its reports pointed out that the NPAs still pose a significant threat to the banking sector. Consequences of NPA are manifold such as reduction in interest income, increased provisions, strained profitability, inability to meet rising cost, stresses on Net Interest Margin (NIM) bringing down competitiveness, gradual depletion of capital and obstacles in capital augmentation

In India, the banks have witnessed a manifold hike in their Gross NPA (GNPA) from 2008 to 2017. The Gross advances of banks has increased from Rs. 2503431 crore to Rs. 8476702 crore and the GNPA increased from Rs. 56606 to Rs. 790268 crores during this periods (Reserve Bank of India, 2018). A surge in bad loans is majorly attribute to sluggish domestic as well as global economic growth, which

Revised Manuscript Received on July 22, 2019.

Salini. R. Chnadran, Department of Banking Management, Akagappa University, Karaikudi, TamilNadu, India. Email: ramachandran.salu@gmail.com

Dr. K. Alamelu, Department of Banking Management, Alagappa University, Karaikudi, TamilNadu, India. Email: alakkn@gmail.com in turn discouraged companies to invest in new projects and to repay their loans and interest to the banks. Increased financial deepening, increased competition, and lower volume of NPAs in the pre- crisis period, rapid product innovations, infrastructure, farm credit and retail sectors lead to aggressive credit expansion by banks in the aftermath of the crisis. This credit expansion in turn opened the door for fresh NPAs in the banks. The withdrawal of funds by foreign investors and slothful industrial growth, also added to the NPA woes of the banks.

\section{STATEMENT OF THE PROBLEM}

An economy flourishes with the support of effective financial intermediation by the banks. Bank credit ignites the growth engine of an economy. In the process of credit management Non Performing Assets are inevitable. NPA is a virus affecting banking sector. It affects liquidity and profitability, in addition posing threat on quality of asset and survival of banks (Singla and Narula, 2014). The higher amount of NPA's indicates an intense possibility of a high number of credit defaults that have an effect on profitability and value of banks and also corrodes the efficacy of the asset. The shooting up NPA call for prerequisite of provisions, which shrink the overall profits and shareholders. In the current scenario, NPAs are at number-one of financial problems of the banks. Solid efforts have to be made to ameliorate recovery execution. Some grounds of rising NPAs are the target-oriented perspectives which worsen the qualitative aspect of lending by banks and intended defaults, unproductive supervision of loan accounts, meagreness of technical and managerial prowess on the part of borrowers (Shah and Mandhanya, 2018).Apart from these, poor management in the banking institutions results in bad quality loans, and therefore, escalates the level of non-performing loans (Berger and DeYoung, 1997).Voluminous Non Performing Asset affects all the stakeholders of banks. They shake the confidence of the depositors and the investors. It creates risk aversion among the bank to lend. This in turn affects the availability of credit as well as the financial stability of the system. Lower volume of bank credit may push up the rate of interest and bring down the flow of funds to the infrastructural and other productive sector. As a consequence the overall demand in the economy may come down. In short rising Non Performing Asset will 
have a cascading effect on the fundamentals of a bank and affect all sections of the society. Poor asset quality of banks is thus an important deterrent of economic growth. In this background an attempt is made to probe in to the reasons of NPA and its consequences on asset quality of banks by taking into account the perception of bank employees on these aspects.

\section{OBJECTIVES}

a) To study the trends in the NPA of banks in India

b) To examine the bankers' perception on the reasons of NPA and their impact on asset quality

c) To suggest measures for managing Non Performing Assets

\section{REVIEW OF LITERATURE}

Chilukuri et al (2016)examined status of quality assets of Indian banking industry in relation to Non-Performing Assets to advances of all Scheduled Commercial Banks for 12 years from 2001-02 to 2012-13 based on secondary source of information retrieved from "Handbook of Statistics on the Indian Economy 2013-2014". The study observed that there is major penetration of advances from Public Sector Banks indicating higher share among all Scheduled Commercial Banks and there is tremendous increase in advances and NPAs over the period of study.

Nitin and Kesari( Sep 2016)attempted to study the situation of NPA of the public and private sector banks in past one decade since 2006. The data collected from the secondary sources were analysed using ratio analysis. It was found that NPAs of public sector banks are relatively higher than that of private sector banks. The study reveals that global economic slowdown and its impact on Indian economy was the primary reason for rising of the NPAs. Looking at the results it is suggested that banks should work to strengthen their recovery channels for the speedy recovery from NPAs.

Nithin et. al(2018) in their study on "NonPerforming Assets and Technical Efficiency of Indian banks: a meta - frontier analysis" concentrates on the mounting NPAs of Indian banking industry and the adverse effect of NPA on the technical efficiency of banks. Using a Meta frontier data envelopment analysis frame work they found that the effect of NPAs on over al technical efficiency and its various components is insignificant. The major source of inefficiency is technology gap among public, domestic private and foreign private categories of banks.

Panigrahi (2018) conducted a study on the non-performing assets of SHGs from bankers' perspective in rural areas of Mayurbhanj and Keonjhar districts of Odisha. It covers banker's opinion towards the prudential norms of bank for loan processing, causes of NPAs and techniques for recovery of NPAs, etc. The data has been collected through a structured questionnaire. The sample for the study consists of 52 managerial and 8 non-managerial staff from different banks of rural areas of Mayurbhanj district of Odisha. The major causes for NPAs in SSGs as reported by bankers are lack of awareness, lack of persuasion and Govt. Scheme. In banker's opinion legal action and one-time settlement (OTS) are the most effective techniques for recovering NPAs from the defaulters

\section{METHODOLOGY}

The study is mainly based on primary data The Primary data on the reasons and consequences of NPA were collected from the executives representing all the three levels of management viz., lower level, middle level and senior level. The total sample size is 160 which were divided in to This was helpful for better understanding of asset quality perception of bankers at various levels of management.20 senior level employees, 120 middle level employees and 20 lower level employees.. The data were analysed with the help of statistical tools such as percentages, growth rates, mean, standard deviation and Chi- square test and $\mathrm{z}$ test.

In order to support the findings of the study, secondary data were also used for a period of 16 years from 2002 to 2017 . The data were collected from RBI publications, annual reports of banks and journals.

\section{DATA ANALYSIS AND INTERPRETAION}

\section{A. Trends in NPA of banks}

The operational efficiency of bank is determined by the volume of NPA of the bank. So the study set its one of its objectives as to know the trend in the NPA of banks in India. The details are depicted in the following Table. 
Table 1 Bank group wise GNPA of Banks in India during

\begin{tabular}{|c|c|c|c|c|c|c|c|c|c|}
\hline \multirow[b]{2}{*}{ Year } & \multicolumn{2}{|c|}{ PSBs } & \multicolumn{2}{|c|}{ OPSBs } & \multicolumn{2}{|c|}{ NPSBs } & \multicolumn{2}{|c|}{ FBs } & \multirow{2}{*}{ 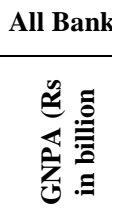 } \\
\hline & 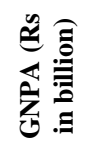 & 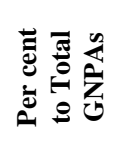 & 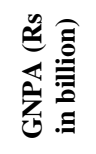 & 造恶这 & 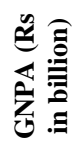 & 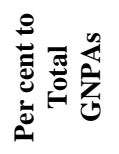 & 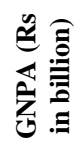 & 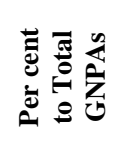 & \\
\hline 2002 & 565 & 79.6 & 46 & 6.5 & 70 & 9.9 & 28 & 3.9 & 710 \\
\hline 2003 & 541 & 75.4 & 43 & 6.2 & 75 & 14.2 & 29 & 4.2 & 688 \\
\hline 2004 & 515 & 79.4 & 44 & 6.8 & 60 & 9.2 & 30 & 4.6 & 649 \\
\hline 2005 & 484 & 81.1 & 42 & 7.2 & 46 & 7.8 & 23 & 4.0 & 587 \\
\hline 2006 & 414 & 80.8 & 37 & 7.3 & 40 & 7.9 & 21 & 4.0 & 512 \\
\hline 2007 & 390 & 76.6 & 30 & 5.9 & 63 & 12.5 & 24 & 4.9 & 505 \\
\hline 2008 & 405 & 71.1 & 26 & 4.6 & 104 & 18.7 & 31 & 5.6 & 565 \\
\hline 2009 & 450 & 64.5 & 31 & 4.5 & 139 & 20.3 & 73 & 10.7 & 693 \\
\hline 2010 & 599 & 70.8 & 36 & 4.3 & 140 & 16.5 & 71 & 8.4 & 847 \\
\hline 2011 & 746 & 76.3 & 37 & 3.8 & 145 & 14.8 & 51 & 5.2 & 979 \\
\hline 2012 & 1125 & 82.6 & 42 & 3.0 & 143 & 10.1 & 63 & 4.4 & 1421 \\
\hline 2013 & 1645 & 84.8 & 52 & 2.8 & 156 & 8.0 & 80 & 4.3 & 1932 \\
\hline 2014 & 2273 & 86.2 & 60 & 2.2 & 183 & 6.93 & 116 & 4.3 & 2634 \\
\hline 2015 & 2785 & 86.1 & 92 & 2.8 & 245 & 7.19 & 108 & 3.3 & 3233 \\
\hline 2016 & 5400 & 88.2 & 118 & 1.9 & 440 & 7.19 & 158 & 2.5 & 6116 \\
\hline 2017 & 6847 & 86.5 & $932 *$ & NA & NA & 11.8 & 136 & 1.7 & 7918 \\
\hline verage & 1574 & 79.4 & 104 & 4.7 & 137 & 11.43 & 65 & 4.8 & 1874 \\
\hline
\end{tabular}

2002 to 2017.

Source: Reports on Trend and Progress of Banking in India, RBI, various year

The Table reveals that among the bank groups public sector banks are having highest share of GNPA compared to other bank groups. Its share in total NPA of the system had increased by 6.9 per cent and its average share is identified at 79.4 per cent from 2002 to 2017. PSBs' share of GNPA in the total GNPAs of the system had exceeded 80 per cent in half of the study period ( 8 years); it was more than 70 per cent in all years of the study period except in 2009. During 2004-2009 (comprising of mostly pre crisis years) the share of GNPA of PSBs had fallen by 16.6 per cent. Old Private Sector Banks (OPSBs) too witnessed a fall in their share of GNPA during 2004-2009 by 2.77 per cent. Conversely the share of GNPAs of New Private Sector Banks (NPSBs).and foreign banks had increased by 12.5 per cent and 6.7 per cent respectively during 2004-2009. During 2010-2017, PSBs registered substantial increase in their share of GNPA ( 15.7 per cent) while the other three segments managed to decrease their shares of GNPA.

\section{B. Asset quality of PSBs - bankers' perception}

Asset quality gaining more importance since the operational efficiency of banks is directly linked to it. So the Government of India and Reserve Bank of India introduced many policies to get rid of the problem of NPA and thus improve the asset quality of banks. Hence an effort is also taken to know the perception of bankers on these aspects. The primary data were collected from the employees of all the PSBs through a well-structured questionnaire. The analysis covers the perception of bankers on the reasons of NPAs, impact of NPA on banks performance and the NPA management measures taken by banks. While choosing the respondents much care was exercised to ensure that they have adequate expertise and experience in credit management.

\section{Reasons/Causes of NPAs}

There are a number of reasons for the occurrence of NPA in banks. Knowledge about such reasons may help bankers to take suitable remedial actions. Table 2 brings out the ranking given by the respondents for the reasons behind NPA/ deteriorating asset quality of banks. 
Majority of the respondents (59.3) opined that both

\begin{tabular}{|c|c|c|c|c|c|c|c|}
\hline \multirow{2}{*}{ S1.No. } & \multirow{2}{*}{ Reasons } & \multicolumn{2}{|c|}{ Senior level } & \multicolumn{2}{c|}{ Middle level } & \multicolumn{2}{c|}{ Lower level } \\
\cline { 2 - 7 } & & Mean & Rank & $\begin{array}{c}\text { Mea } \\
\text { n }\end{array}$ & Rank & Mean & Rank \\
\hline 1 & wilful default & 6.30 & 1 & 6.01 & 1 & 2.50 & 5 \\
\hline 2 & $\begin{array}{c}\text { Siphoning of funds for other } \\
\text { purposes }\end{array}$ & 6.30 & 1 & 5.80 & 2 & 6.70 & 2 \\
\hline 3 & Ineffective monitoring & 3.56 & 3 & 5.48 & 3 & 5.25 & 3 \\
\hline 4 & Lax in credit appraisal & 3.00 & 4 & 3.40 & 4 & 7.50 & 1 \\
\hline 5 & Economic downturn & 4.10 & 2 & 3.08 & 5 & 1.00 & 6 \\
\hline 6 & Political pressure & 1.8 & 5 & 2.96 & 6 & 4.45 & 4 \\
\hline 7 & Increasing Rate of Interest & 1.5 & 6 & 2.50 & 7 & 5.25 & 3 \\
\hline
\end{tabular}

\section{Table 2 Major Reasons for NPA}

\section{Source: Primary Data.}

The Table reveals that both the senior level and It could be observed from the Table that, majority of the respondents (59.4 per cent) opined that the contribution of MSME is significant in priority sector NPA. 21.3 per cent identified the agriculture sector as the dominant force in priority sector NPA.

The study also attempted to test the statistical significance of various borrowers specific and banker related reasons of growing NPA of banks. The test result is depicted in Table 5.

middle level management states that wilful default from the part of the borrowers are the major reason for increased NPA of the banks followed by siphoning of funds for other purposes other than the original purpose of loan taken. But, executives at the branch level were of the opinion that lax in credit appraisal always lead to NPA. Economic downturn and recessionary trends were identified as the second vital reason for the NPA by senior management executives of banks. Their opinion coincides with the findings of Siraj, KK and Pillai, PS (2011) and the comments of Sinha, Deputy Governor RBI (2011) that aggressive lending by PSBs during the boom periods and the impact of financial crisis contributed more to their NPA.

\section{Sectoral Contributions of NPAs}

The lending by banks can be broadly classified in to two priority sector and non-priority sector lending. An attempt is also made to get the opinion of the bankers on the composition of NPA in terms of priority sector and non-priority sector and the details are depicted in Table 3.

\begin{tabular}{|c|c|c|}
\hline Sectors & Frequency & Percent \\
\hline Priority Sector & 50 & 31.2 \\
\hline Non-Priority Sector & 15 & 9.3 \\
\hline Both have equal contribution & 95 & 59.3 \\
\hline Total & $\mathbf{1 6 0}$ & $\mathbf{1 0 0}$ \\
\hline
\end{tabular}

priority and non- priority sector contributes to the NPA of banks. 31 per cent of the respondents stated that priority sector lending act as the major reason for NPA and the remaining 9 per cent of the respondents stated that non-priority sector contributes to NPA of banks.

Priority sector comprises of agriculture, micro and small and medium enterprises and other sectors. The following Table 4 exhibits the opinion of the bankers about the contribution of different segments of priority sector to the total NPAs of banks. 


\begin{tabular}{|c|c|c|}
\hline Particulars & Frequency & Percent \\
\hline Agriculture Sector & 30 & 18.8 \\
\hline MSME & 95 & 59.4 \\
\hline Others & 35 & 21.8 \\
\hline Total & 160 & 100 \\
\hline
\end{tabular}

\section{Table 4 Priority Sector NPAs - Bankers' Perceptions}

Source: Primary Data

It could be observed from the Table that, majority of the respondents (59.4 per cent) opined that the contribution of MSME is significant in priority sector NPA. 21.3 per cent identified the agriculture sector as the dominant force in priority sector NPA.

The study also attempted to test the statistical significance of various borrowers specific and banker related reasons of growing NPA of banks. The test result is depicted in Table 5. Table 5 The Significance of Various Reasons
-3.751 is lesser than the Table value of 3.75 . So there is no statistical significance implying that time and cost over runs do not influence the level of NPA much. Regarding delay in sanctioning of limits/settlement of dues/subsidies, calculated Z-value of 7.503 is greater than the Table value implying that delayed credit facilities and subsidy payments may affect the repaying capacity of the borrower leading to NPA. Wilful default and misuse of funds significantly affect the level of NPA as the calculated Z-value of 32.281 is much higher than the Table value. The weak management and strained industrial relations has no impact on the increased NPA of

\begin{tabular}{l|c|c|c|c|c|c}
\hline No & Significance of Various Causes for NPA & Mean & S.D & $\begin{array}{c}\text { Mean\% } \\
\text { Score }\end{array}$ & Z-Value & Significs \\
\hline 1. & $\begin{array}{c}\text { Constraints in project implementation due to time } \\
\text { over run and cost overrun. }\end{array}$ & 3.2892 & 1.072 & 65.75 & -3.571 & Not Signi \\
\hline 2. & $\begin{array}{c}\text { Delay in sanctioning of limits/settlement of } \\
\text { dues/subsidies. }\end{array}$ & 3.8020 & 0.7169 & 76.00 & 7.503 & Signific \\
\hline 3. & Wilful default & 4.2509 & 0.746 & 85.00 & 18.271 & Signific \\
\hline 4. & Weak management and disputes industrial \\
relations & 3.5150 & 0.990 & 70.25 & 0.326 & Not Signi \\
\hline 5. & \begin{tabular}{c} 
Improper technology \\
\hline 6.
\end{tabular} & 3.8590 & 0.872 & 77.00 & 7.206 & Signific \\
\hline 7. & Unrealistic Feasibility studies & 3.7636 & 0.892 & 75.25 & 5.305 & Signific \\
\hline 8 & Changes in government policy & 3.9896 & 0.764 & 79.75 & 11.611 & Signific \\
\hline
\end{tabular}

\section{Source: Primary Data}

The Table reveals that among the various reasons statements such as 'delay in sanctioning of limits/settlement', wilful default, improper technology, unrealistic feasibility studies and changes in government policy are having significant influence in rising NPA of banks. All the other reasons do not have a significant influence on the rising NPA of banks.

In case of constraints in project implementation due to time over run and cost overrun, the calculated $\mathrm{Z}$-value of banks. The same can be seen in case of improper management and it does not create significant NPA as the calculated $\mathrm{Z}$-value of 0.226 is lesser than the Table value

\section{Financial Crisis}

The year 2008, considered as a crisis period of the entire banking system. This is called sub- prime bubbles which had put excessive pressure on the loan portfolio of banks, globally. Even though the Indians banks were not that 
much affected by the crisis, their asset quality strained to a great extent.

The responses of the executives of banks reveal that financial crisis affected the Indian banking system moderately (49 percent). Thirty percent of the respondents stated that it has high impact on the banking system and only 16 percent opined that financial crisis created low impact over the banking system.

Table 6 Impact of Financial Crisis provisions. Rankings given by middle level executives and lower level executives are more are less similar.

\section{F. Other consequences of NPA}

The NPA is considered as a nightmare of Indian banking system. It affected the performance of banks in many ways. The above listed table mentioned only few of them. Apart from that, it has impact on Indian banking system. The other after affects and their $\mathrm{z}$ - values are given in Table 8 .

\begin{tabular}{|c|c|c|}
\hline Particulars & Frequency & Percent \\
\hline High & 56 & 35 \\
\hline Medium & 78 & 49 \\
\hline Low & 26 & 16 \\
\hline Total & 160 & 100.0 \\
\hline \multicolumn{3}{|c|}{ Source: Primary data } \\
\hline
\end{tabular}

\section{E. Consequences of NPA}

NPA not only affect the banks but also affect the lenders, borrowers, depositors, Government and the economy. It is clearly understood that size of the balance sheet alone does not determine the efficiency of a bank; it also depends upon the return on assets (Prasad and Veena, 2011). NPA may erode the asset quality, reduce cash flows to the bank, increase the amount of provisions and compel banks to go for high cost funds. It may also have the negative impact on the morale of bankers and the reputation of banks.

The consequences of NPA were identified through extensive literature review and the respondent's perception on each consequence is collected and ranked accordingly. The Ranking given by the respondents are depicted in Table 7

Table 7 Management Perception of Impact of NPA

\begin{tabular}{|c|c|c|c|c|c|c|}
\hline \multirow{2}{*}{ Level } & \multicolumn{2}{|c|}{ Senior level } & \multicolumn{2}{c|}{ Middle level } & \multicolumn{2}{c|}{ Lower level } \\
\cline { 2 - 7 } & Mean & Rank & Mean & Rank & Mean & 1 \\
\hline Erosion of profit & 5.45 & 1 & 5.40 & 2 & 5.78 & 2 \\
\hline Enhanced provisioning & 5.45 & 1 & 5.52 & 1 & 5.10 & 4 \\
\hline High intermediation cost & 3.83 & 3 & 3.48 & 3 & 2.71 & 3 \\
\hline Wafer thin margin & 1.5 & 5 & 3.60 & 4 & 3.42 & 5 \\
\hline Affects the reputation & 3.97 & 2 & 2.69 & 5 & 2.60 & 5 \\
\hline More market borrowings & 2.38 & 4 & 1.89 & 6 & & 5 \\
\hline
\end{tabular}

Source: Primary Data

It could be observed from the table that, Senior level executives and lower level executives have given the first rank to the impact of NPA on profit but middle management executives' have given the first rank to the impact of NPA on 


\begin{tabular}{|l|c|c|}
\hline \multicolumn{1}{|c|}{ Consequences } & Mean (\%) & Z-value \\
\hline Liquidity crisis and high cost of borrowing & 75.50 & 5.041 \\
\hline Rate of interest & 71 & 0.742 \\
\hline Credit growth & 69 & -0.808 \\
\hline Banks' investments & & -11.638 \\
\hline
\end{tabular}

\section{Table 8 Other consequences of NPA}

In other words emergence of NPA will be followed by liquidity crisis and high cost of borrowing. The relationship between NPA and liquidity is statistically significant as the Z-value is 5.041.The relationship between NPA and credit growth is inverse, proved with a Z-value of -0.808 . When the bankers were asked to react about the impact of NPA on investment, they said that level of NPA determine the investment portfolio composition of banks. But this relationship is not statistically significant as the $\mathrm{Z}$-value is -11.638 .

\section{F. Management of NPA}

Management of NPA is a complex process .The Government of India and the RBI has initiated a series of measures for improving the process of NPA management. Prudent management of NPA calls for both preventive measures and curative measures. Preventive measures include the precautions to be taken by a bank in the pre-sanction and the post-sanction stages of credit. Curative measures help to reduce a NPA in the balance sheet through various modes of recovery. The bankers are asked to rate the various NPA management measures and the result is tabulated in Table 9. compromise with the borrowers and proper reporting of frauds were given the next three ranks with mean score of $3.2013,2.9842$ and 2.6072 respectively. Thus, it is understood that effective risk management is the need of the hour

\section{G. Periodical Review of Loan Portfolio}

Every loan sanctioned by a bank needs periodical review. Such reviews may help banks to get clues about the health of an account. Banks may know the status of an account becoming NPA, if the review is scientific and done at regular intervals. Majority of the respondents ( 81 per cent) gave almost a uniform opinion about the existence of such regular reviews.

Table 9 Ranking of Various NPA Management

\begin{tabular}{|c|c|c|}
\hline NPA Management measures & Mean & Rank \\
\hline 1. Proper assessment and management of risk & 4.4782 & 2 \\
\hline 2. Sharing of credit information & 4.3211 & 3 \\
\hline 3. Disclosure of wilful defaulter & 4.2232 & 4 \\
\hline 4. Better collateral norms & 3.2013 & 5 \\
\hline 5. Compromise with borrower & 2.9842 & 6 \\
\hline 6. Proper reporting of frauds & 2.6072 & \\
\hline
\end{tabular}

\section{Mechanisms}

Source: Primary Data

Banks view proper assessment and management of risks as the most powerful technique of NPA management (Mean=4.4782). Adequate and timely sharing of credit information got the second rank with a mean score of 4.3211 . Prompt disclosure of wilful defaulters was assigned the third rank with a mean score of 4.2232. Better collateral norms, 


\begin{tabular}{|c|c|c|}
\hline Particulars & Frequency & Percent \\
\hline Yes at regular intervals & 130 & 81 \\
\hline Yes, but occasionally & 28 & 18 \\
\hline Yes, but only when the loan repayment is disturbed & 2 & $\mathbf{1 0 0 . 0}$ \\
\hline Total & $\mathbf{1 6 0}$ & \\
\hline
\end{tabular}

Table 10 Periodical Review of Loan Portfolio

Source: Primary Data

H. Coordination with Industrial Bodies for Better NPA Management

While formulating NPA management policy banks can consult apex bodies of industries such as chambers of commerce, industry specific association in order to have pragmatic credit decisions. This view was endorsed by 70 per cent of the respondents as given in Table 11. But the relationship is not statistically significant as the $\mathrm{Z}$-value is $-6.841$

Table 11Co Ordination with Industrial Bodies for Better NPA management
I. Strengthening the Credit Department Perception of the Respondents

Credit department is one of the vital organs of a bank. While devising the HRD policies due focus should be given for the recruitment of right type of personnel. Due weightage should be given for training and development of employees in credit department. There should be a scientific performance appraisal and reward system.

When a poser was made about the need for strengthening the credit department and the measures to be taken all respondents felt that a strong credit department will address the problem of NPA effectively. The suggestions

\begin{tabular}{|c|c|c|c|c|}
\hline Particulars & Frequency & Percent & Mean \% Score & Z-Value \\
\cline { 1 - 3 } Strongly Agree & 64 & 40 & & \\
Agree & 48 & 30 & & \\
\cline { 1 - 3 } Neither Agree nor Disagree & 16 & 10 & \multirow{2}{*}{62.50} & -6.841 \\
\hline Disagree & 32 & 20 & \\
\hline Strongly Disagree & 0 & 0 & \\
\hline
\end{tabular}

Source: Primary Data

given by them for strengthening the credit department are given in Table 12.

Table 12 Measures to be taken for Strengthening the

\begin{tabular}{|c|c|c|}
\hline Measures & Frequency & Per cent \\
\hline 1. Recruitment of personnel with specialized skills. & 80 & 50 \\
\hline 2. Regular training programmes. & 40 & 25 \\
\hline 3. Incentives for additional qualification. & 60 & 46 \\
\hline 4. Incentives for prompt recovery of skills. & 110 & 69 \\
\hline 5. More exposure to information technology for effective appraisal & 120 & 75 \\
\hline 6. Performance based pay & 90 & 56 \\
\hline
\end{tabular}

\section{Credit Department}

Source: Primary Data 


\section{J. Efficacy of Recovery Channels}

There are three important channels meant for recovery of NPAs viz., Lok Adalats, DRT and SARFAESI Act. Most of the bankers felt that the SARFAESI Act is the most efficient channel of recovery as given in Table 13

Table 13 Efficacy of Recovery Channels
Act is realized by most of the bankers. The Z-value of 3.203 explains that the recovery channel lacks efficiency.

\section{K. Remarks on Asset Quality - Statistical Significance}

While undertaking the research, the researcher had interacted with experienced academicians and versatile

\begin{tabular}{|c|c|c|c|c|}
\hline Channels of recovery & $\begin{array}{c}\text { No. of } \\
\text { respondents }\end{array}$ & Per cent & $\begin{array}{c}\text { Mean \% } \\
\text { Score }\end{array}$ & Z-Value \\
\cline { 1 - 3 } Lok Adalats & 20 & 12 & \multirow{2}{*}{74.50} & \multirow{2}{*}{3.203} \\
\cline { 1 - 3 } DRT & 30 & 19 & \\
\cline { 1 - 3 } SARFAESI Act & 100 & 63 & \\
\cline { 1 - 3 } ARC & 10 & 6 & & \\
\hline
\end{tabular}

Source: Primary Data

SARFAESI Act is very effective in the recovery of NPA. It gives powers to banks to auction collateral in the event of borrowers' default. The significance of SARFAESI bankers. In the course of such discussion few notable remarks were observed. The statistical significance of such observations was tested with the help of mean, percentage score and z-value.

Table 14 Various Remarks on NPA - Statistical significance

\begin{tabular}{|c|c|c|c|c|c|}
\hline Observations & Mean & S.D & $\begin{array}{l}\text { Mean \% } \\
\text { Score }\end{array}$ & $Z$ value & Significance \\
\hline $\begin{array}{l}\text { Reduction of fre sh NPA every year lead } \\
\text { to reduction is NPA ratio. }\end{array}$ & 1.925 & .982 & 39.00 & -28.44 & Not Significant \\
\hline $\begin{array}{l}\text { Higher level of credit growth over the } \\
\text { years led to low level of NPA. }\end{array}$ & 2.0882 & 1.0283 & 41.75 & -24.56 & Not Significant \\
\hline $\begin{array}{l}\text { There is a gradual improvement in the } \\
\text { efficacy of recovery process of NPA. }\end{array}$ & 1.9876 & .64326 & 39.75 & -42.06 & Not Significant \\
\hline $\begin{array}{l}\text { Regulatory measures fail to arrest the } \\
\text { occurrence of fresh NPA. }\end{array}$ & 2.0266 & .96295 & 40.50 & -27.40 & Not Significant \\
\hline $\begin{array}{l}\text { Incremental NPA are growing swiftly } \\
\text { then advances. }\end{array}$ & 2.2042 & 1.11317 & 44.00 & -20.893 & Not Significant \\
\hline $\begin{array}{l}\text { Most of the NPA management measures } \\
\text { are curative and not preventive. }\end{array}$ & 3.9883 & .75129 & 79.75 & 11.611 & Significant \\
\hline $\begin{array}{c}\text { Regulations of NPA are more borrower } \\
\text { friendly. }\end{array}$ & 4.5765 & .58787 & 91.50 & 32.718 & Significant \\
\hline The recovery mechanism of NPA is rigid. & 4.1137 & -63343 & 82.25 & 17.300 & Significant \\
\hline
\end{tabular}

Source: Primary Data

The table reveals that the statements such as 'Most of the NPA management measures are curative and not preventive', Regulations of NPA are more borrowers friendly' and 'Recovery mechanism of NPA is rigid 'are found to be statistically significant with respect to NPA management of banks. All the other statements are not significant.

\section{CONCLUSION}

The analysis clearly found that over the years there is increase in the NPA of banks. While collecting the opinion of bankers it is understood that they are severely affected with the growing NPA. They pointed out that though NPA arise due to various internal and external factors, wilful default often leads to more NPA. They conceded that NPAs pose serious threat to the profitability and goodwill of the bank. They expressed the hope that ongoing measures such as professionalization of the credit department, introduction of Insolvency and Bankruptcy Code, transparency in credit reporting etc., will improve the asset quality of banks in the long run.

\section{REFERENCES}

1. Brown J. D. (2001) Using Surveys in language Programs, $I^{\text {st }}$ Edition Cambridge University Press P. 176.

2. Carmines, E.G.and Zeller, R.A. (1979), "Reliability and Validity Assessment", Sage Publications, USA, p. 11-12.

3. Chakrabarty, K.C. (2012), Supporting Explosive Growth: Effective Linkages between the Banking Sector and Real Sector, 8th Annual Banking Summit ASSOCHAM, New Delhi, Online: http://www.rbi.org.in/scripts/BS SpeechesView.aspx?Id=754

4. Chilukuri, S. S., Srinivas, R. K., and Madhav, V. V. (2016). An Empirical Analysis on Asset Quality of Indian Banking Industry Nonperforming Assets to Advances. Journal of Accounting \&Marketing. 
5. Chipalkatti, N and Rishi, M (2007), Do Indian Bank understate their bad loans, The Journal of Developing Areas, Volume 40, Number 2, Spring 2007, pp. 75-91

6. Connaway, L.S. and Powell, R.R. (2010), "Basic Research Method for Librarians”, Library of Congress Cataloging-in-Publication Data, p.63

7. Dukes, K. A. (2005), Cronbach's Alpha. Encyclopedia of Biostatistics, John Wiley and Sons Limited, USA

8. Funk, R.,Ives, M. and Dennis, M. (2007), "Reliability - Calculating Cronbach Alpha”, LI Analysis Training Centre,[Online], URL: http://www.chestnut.org/LI/downloads/training_memos/Alpha.pdf.

9. Joppe, M. (2000), The Research Process.,[Online], URL: http://www.ryerson.ca/ mjoppe/rp.htm.

10. Khan, M.Y (2004), Financial Services, Third Edition, Tata McGraw Hill ,Publications, p.16.32

11. Kumar, R. (2010), Increased Importance of Credit Appraisal Process in Today's Banking Landscape,Tejas@IIMB, [Online], URL; http://tejas-iimb.org/interviews/15.php, Date Accessed: $15^{\text {th }}$ January 2012.

12. Nitin Arora, Nidhi Grover Arora, Kritika Kanwar, (2018) "Non-performing assets and technical efficiency of Indian banks: a meta-frontier analysis", Benchmarking: An International Journal, Vol. $25 \quad$ Issue: 7 , pp.2105-2125, https://doi.org/10.1108/BIJ-03-2017-0040

13. Nunnaly, J. (1978). Psychometric theory, New York: McGraw-Hill.

14. Panigrahi, K. (2018). NPA MANAGEMENT-A BANKERS'PERSPECTIVE IN RURAL ODISHA. Srusti Management Review, 11(1), 47-51.

15. Prasad, V.B. and Veena, D. (2011), NPAs Reduction Strategies for Commercial Banks in India, International Journal of Management \& Business Studies, Vol. 1, Issue 3, pp. 47-53.

16. Ronald Ravinesh Kumar, Peter Josef Stauvermann, Arvind Patel, Selvin Sanil Prasad, (2018) "Determinants of non-performing loans in banking sector in small developing island states: A study of Fiji", Accounting Research Journal, Vol. 31 Issue: 2, pp.192-213, https://doi.org/10.1108/ARJ-06-2015-0077

17. Sinha (2011), Rise in NPAs, slippages need to be urgently addressed, BANCON 2011 [Online], URL:http://www.thehindu.com/news/states/tamilnadu/article2605920 ece?css=print

18. Siraj, K.K. and Pillai, P.S. (2011), Asset Quality and Profitability of Indian Scheduled Commercial Banks During Global financial crisis, International Research Journal of Finance and Economics, Issue 80, 2011.

19. Siraj, KK and Pillai, PS (2011), Asset Quality and Profitability of Indian Scheduled Commercial Banks During Global financial crisis, International Research Journal of Finance and Economics, Issue 80, 2011.

20. Straub, D., Boudreau, M.C., and Gefen, D. (2004), Validation Guidelines for IS Positivist Research, Communications of the Association for Information systems, 13, pp.380-427

21. Swamy, V (2012), Impact of Macroeconomic and Endogenous factors on Non Performing Bank Assets, The International Journal of Banking and Finance, Volume 9 (Number 1) 2012: pages 27-47

22. Uppal, RK (2009), Priority sector advances: Trends, issues and strategies,Journal of Accounting and Taxation Vol.1 (5), pp. 079-089. 